\title{
Upaya Meningkatkan Kualitas Produk PD. X Dengan Menggunakan Metode Importance Performance Analysis dan Kano
}

\author{
Husni Izza Maulana \\ Program Studi Teknik Industri, Universitas Indraprasta PGRI, Jakarta \\ mr.husni10@gmail.com
}

\begin{abstract}
Abstrak - PD. X adalah salah satuperusahaan terbesardi kota Cirebon dalam bidangpembuatan saus dan kecap. Namun seiring semakin ketatnya persaingan yang kompetitif, seperti inovasi-inovasi dari para pesaing. Berpotensi memberi pengaruh yang signifikan terhadap penjualan produk. Penelitian ini bertujuan untuk mengetahui kepuasan pelanggan terhadap kualitas produk dari PD.X, terutama pada produk sausnya. Dan mengidentifikasi keluhan pelanggan terhadap produk PD. X. Penelitian ini dilakukan dengan survei melalui kuesioner responden, kemudian dilanjutkan dengan analisis data hasil penelitian. Analisis dilakukan dengan menghitung Custumer Satisfaction Index kemudian dilanjutkan dengan integrasi dari metode Importance Perfomance Analysis dan model KANO.Hasil penelitian diperoleh hasil nilai indeks kepuasan pelanggan terhadap produk saus PD. X sebesar 35,25\% dan termasuk dalam kategori kurang puas. Dalam upaya meningkatkan nilai indeks tersebut diperoleh beberapa atribut yang menjadi prioritas untuk diperbaiki ataupun dipertahankan, seperti cita rasa dari saus, masalah harga dari produk, jaminan, dan kekuatan produk.
\end{abstract}

Kata kunci-Produk Saus, Importance Performance Analysis, KANO

\begin{abstract}
PD. X is one of the largest companies in the city of Cirebon in the field of making sauce and soy sauce. But along with the increasingly tight competition, such as innovations from competitors. Potential to have a significant influence on product sales. This study aims to determine customer satisfaction with the quality of products from PD. X, especially on the sauce products. And identify customer complaints about PD products. X. This research was conducted with a survey through the respondent's questionnaire, then continued with the analysis of research data. The analysis is carried out by calculating the Custumer Satisfaction Index then proceeding with integration of the Importance Perfomance Analysis method and the KANO model. The results of the study obtained the results of the customer satisfaction index for PD sauce products. $X$ is $35.25 \%$ and is included in the category of dissatisfaction. And in an effort to increase the index value, several priority attributes to be repaired or maintained, such as the taste of sauce, the price issue of products, guarantees, and product strength are obtained.
\end{abstract}

Keywords - Sauce Product, Importance Performance Analysis, KANO

\section{PENDAhUluan}

$\mathrm{S}_{\mathrm{n}}^{\mathrm{a}}$ aos sambal sudah menjadi kebutuhan mendasar bagi masyarakat saat ini. Seperti saat menjelang musim hujan, orang akan banyak mencari makanan pedas [1]. Terutama bagi kalangan tukang bakso dan mie ayam, saos sambal merupakan salah satu kunci dari cita rasa dari dagangan mereka. Pada era globalisasi ini, disadari bahwa pentingnya konsep yang lebih menekankan pada perusahaan yang berwawasan dan mementingkan pelanggan. Konsep ini menempatkan pelanggan pada posisi yang semakin penting bagi perusahaan, karena konsumen dapat menjadi kunci bagi kesuksesan perusahaan. PD Surabraja Food Industry selama bertahun-tahun perusahaan ini berjalan, perusahaan ini belum pernah melakukan pengukuran tingkat kepuasan dari para pelanggannya ataupun karyawannya. Sehingga dalam upaya meningkatkan produktivitas untuk memaksimalkan kualitas masih kurang optimal. Seperti saat mengorder, apakah pelanggan mendapat pelayanan yang baik, produk cacat atau reject masih banyak ditemukan, waktu pengiriman apa sudah cukup baik bagi pelanggan.

Permasalahan seperti ini bagi perusahaan apabila tidak cepat-cepat diatasi, maka dapat menurunkan tingkat kualitas terhadap pelanggan dan produktivitas kurang maksimal. Dengan mengukur tingkat kepuasan pelanggan, perusahaan akan mengetahui tingkat kualitas pelayanannya terhadap pelanggan demi keberlangsungan perusahaan, dan akan lebih optimal jika perusahaan akan meningkatkan produktivitasnya. Kualitas layanan yang dapat memuaskan pelanggan terbukti dapat meningkatkan profitabilitas, sehingga dapat menjadi alat untuk keunggulan bersaing. Kualitas layanan yang baik dapat menciptakan pembelian kembali, differensiasi layanan yang kompetitif positive word of mouth dan loyalitas pelanggan [2]. Tujuan dari penelitian untuk meningkatkan kualitas produk perusahaan dengan harapan dapat meningkatkan juga pemasukan. Penelitian sebelumnya mengenai integrasi metode IPA dan model kano yang dilakukan oleh Balqis (2016), Indrasari (2015) dan Futhila, Lestari, Husna (2016) berhasil mengidentifikasi atribut pelayanan yang menjadi prioritas perbaikan serta atribut yang kurang optimal dan memberikan usulan perbaikan kualitas pelayanan pada perusahaan pelayanan jasa $[3][4][5]$.

\section{METODE PENELITIAN}

Pengujian statistik yang digunakan pada penelitian ini adalah dengan dengan pengujian validitas dan uji reliabilitas. Tujuan dari uji validitas adalah untuk melihat kevalidan suatu data yang dilakukan dengan menghitung korelasi yang dapat dilakukan dengan menggunakan aplikasi 
SPSS. Suatu kuesioner dikatakan valid, jika uji signifikasi dari Rhitung $>$ Rtabel. Untuk menentukan nilai dari Rtabel dapat ditentukan dengan degree of freedom $(\mathrm{df})=\mathrm{n}-2$, dalam hal ini n menunjukan jumlah sampel. Uji reliabilitas bertujuan untuk melihat konsistensi suatu data yang dilakukan dengan menghitung koefisien reliabilitas (alpha cronbach) dengan menggunakan aplikasi SPSS. Suatu kuesioner dikatakan reliabel jika nilai alpha cronbach $>0,60$ [6].

Setelah data valid dan reliabel, langkah berikutnya adalah menganalisis indeks kepuasan pelanggan dengan melihat berapa besar persentase pelanggan yang puas terhadap kualitas produk dengan memperhatikan tingakat kepentingan produk. Nilai maksimum CSI adalah 100\%. Nilai CSI sebesar $50 \%$ atau lebih rendah menandakan kinerja pelayanan yang kurang baik. Adapun berikut table criteria tingkat kepuasan.

\begin{tabular}{ccc} 
& \multicolumn{2}{c}{ Tabel 1 Kriteria Tingkat Kepuasan } \\
\hline No & Nilai CSI $(\%)$ & Keterangan \\
\hline 1 & $81 \%-100 \%$ & Sangat Puas \\
2 & $66 \%-80,99 \%$ & Puas \\
3 & $51 \%-65,99 \%$ & Cukup Puas \\
4 & $35 \%-50,99 \%$ & Kurang Puas \\
5 & $0 \%-34,99 \%$ & Tidak Puas \\
\hline
\end{tabular}

Tahapan perhitungan dari Custumer Satisfaction Index (CSI) dilakukan dengan menentukan Mean Satisfaction Score (MSS), Mean Importance Score (MIS), dan Weight Score (WS). Adapun rumusnya adalah sebagai berkut :

$\mathrm{WS}=\mathrm{MSS} \times \mathrm{MIS}$

$\mathrm{CSI}=\frac{\text { Weight Score }}{5 \times \text { Mean Importance Score }} \times 100 \%$

Nilai 5 pada rumus CSI adalah nilai maksimal pada skala pengukuran.

Importance Performance Analysis (IPA) adalah alat bantu yang digunakan untuk memetakan kinerja/pelayanan yang diberikan dengan harapan yang diinginkan pelanggan digunakan untuk melihat posisi hasil plot antara rata-rata skor kinerja $(\bar{X})$ dan rata-rata skor harapan $(\bar{Y})$ dalam diagram kartesius yang dibagi menjadi 4 kuadran [7]. Penentuan plot kuadran data dilakukan dengan mencari titik perpotongan antara nilai rata-rata tingkat kepuasan dan ratarata tingkat keadaan.Proses ini diawali dengan menentukan nilai $\mathrm{x}$ dan $\mathrm{y}$ sebagai pembatas untuk masing-masing kuadran. Adapun rumusnya :

$\bar{X}=\frac{\sum X i}{n}$

$\bar{Y}=\frac{\sum Y i}{n}$

Diagram kartesius merupakan suatu diagram yang dibagi atas empat kuadran yang dibatasi oleh dua buah baris yang berpotongan tegak lurus pada titik-titik $\bar{X}$ dan $\bar{Y}$. Adapun keterangan dari setiap kuadran dijelaskan sebagai berikut :

Kuadran A: Menunjukkan factor atau atribut yang dianggap mempengaruhi kepuasan pelanggan, termasuk unsur-unsur jasa yang dianggap sangat penting, namun manajemen belum melaksanakannya sesuai dengan keinginan pelanggan sehingga mengecewakan/tidak puas.

Kuadran B : Menunjukkan unsur jasa pokok yang telah berhasil dilaksanakan. Untuk itu wajib dipertahankannya. Dianggap sangat penting dan sangat memuaskan.

Kuadran C : Menunjukkan beberapa faktor yang kurang penting pengaruhnya bagi pelanggan. Pelaksanaannya oleh perusahaan biasa-biasa saja. Dianggap kurang penting dan kurang memuaskan.

Kuadran D : Menunjukkan faktor yang mempengaruhi pelanggan kurang penting, akan tetapi pelaksanaannya berlebihan. Dianggap kurang penting tetapi sangat memuaskan.

Metode Kano adalah suatu metode yang secara logis melakukan penilaian perasaan konsumen mengenai atribut produk/layanan tertentu berdasarkan seberapa baik pelanggan menerima pelayanan yang dirasakannya [7]. Konstruksi model Kano dimulai dengan melakukan survey terhadap pelanggan yang diberikan dua pertanyaan berbeda untuk setiap atribut. Pertanyaan pertama adalah pendapat pelanggan apabila atribut berjalan dengan baik (fungsional), sedangkan pertanyaan kedua adalah pendapat pelanggan apabila atribut tidak berjalan dengan baik (disfungsional). Kemudian dievaluasi menggunakan tabel evaluasi Kano.

\begin{tabular}{|c|c|c|c|c|c|c|}
\hline \multirow{3}{*}{\multicolumn{2}{|c|}{ Kebutuhan Konsumen }} & \multicolumn{5}{|c|}{ Disfungsional } \\
\hline & & 1 & 2 & 3 & 4 & 5 \\
\hline & & $\begin{array}{c}\text { Sangat Tidak } \\
\text { Puas }\end{array}$ & $\begin{array}{l}\text { Tidak } \\
\text { Puas }\end{array}$ & Netral & Puas & $\begin{array}{c}\text { Sangat } \\
\text { Puas }\end{array}$ \\
\hline \multirow{5}{*}{ Fungsional } & $\begin{array}{c}\text { Sangat } \\
\text { Tidak Perlu }\end{array}$ & Q & A & A & A & $\mathrm{O}$ \\
\hline & (1) Tidak Perlu & $\mathrm{R}$ & I & I & I & M \\
\hline & Netral & $\mathrm{R}$ & I & I & I & M \\
\hline & Perlu & & & I & I & M \\
\hline & $\begin{array}{l}\text { Sangat } \\
\text { Perlu }\end{array}$ & $\mathrm{R}$ & $\mathrm{R}$ & $\mathrm{R}$ & $\mathrm{R}$ & Q \\
\hline
\end{tabular}

$\begin{array}{ll}\text { Keterangan } & \\ \mathrm{Q} & \text { : Questionable } \\ \mathrm{R} & \text { : Reverse } \\ \mathrm{A} & \text { : Attractive } \\ \mathrm{M} & \text { : Must Be } \\ \mathrm{I} & \text { : Indefferent } \\ \mathrm{O} & \text { : One-dimensional }\end{array}$

Metode integrasi antara importance performance analysis dan Kano ini merumuskan strategi prioritas penyelesaian atribut-atribut yang perlu dipertahankan dan ditingkatkan dengan cara mengkombinasi hasil metode IPA dan model Kano untuk setiap atribut. Atribut dari Kano dengan kategori indefferent dan reverse harus dieliminasi dan perlu ditinjau ulang kembali serta disosialisasikan kepada pelanggan tentang tujuan indikator tersebut supaya pelanggan dapat memberikan penilaian yang tepat untuk atribut tersebut.

\section{HASIL DAN PEMBAHASAN}

Berdasarkan hasil perhitungan MIS, MSS, dan WS, dapat diperoleh hasil perhitungan Custumer Satisfaction Index.

$$
\begin{aligned}
\mathrm{CSI} & =\frac{3790785}{5 \times 21, \mathrm{9} 8} \times 100 \% \\
& =35,25 \%
\end{aligned}
$$


Nilai CSI yang diperoleh menunjukan bahwa kinerja dari perusahaan masih kurang baik secara keseluruhan dalam memberikan kepuasan kepada pelanggan kategori

Dalam menentukan kategori kedalam setiap kuadran diagram kartesius IPA, terlebih dahulu tentikan nilai $\bar{X}$ dan $\bar{Y}$ sebagai pembatasuntuk masing-masing kuadran.

$\bar{X}=\frac{24}{50} \stackrel{7}{=} 4,94$

$\bar{Y}=\frac{22}{50} \stackrel{7}{=} 4,54$

Berikut diagram hasil kartesius hasil pengolahan dari IPA.

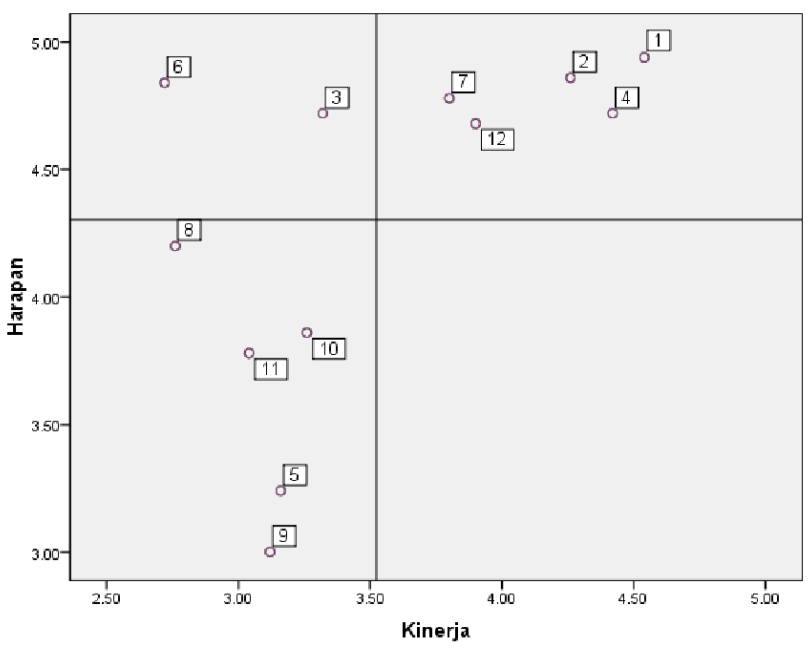

Gambar 1. Diagram Kartesius IPA

Metode Importance Performance Analysisis mengklasifikasikan empat indikator, pada kuadran A mengindikasikan atribut - atribut inilah yang dinilai sangat penting oleh konsumen, namun belum maksimal kinerjanya. Berikut atribut - atribut yang termasuk pada kuadran ini, Produk Mudah didapat (6). Berat bersih produk dalam 1 botol (3). Pada kuadran B mengindikasikan tingkat kinerja perusahaan telah memenuhi apa yang telah diharapkan konsumen. Berikut atribut - atribut yang termasuk pada kuadran ini, Rasa saus yang enak (1), Harga terjangkau (2), Jaminan halal, higienis, dan aman (4), Kebersihan botol saos (7), Jaminan dari perusahaan (12). Pada Kuadran C mengindikasikan kurang penting bagi konsumen, dan kinerja dari perusahaan juga biasa saja. Berikut atribut atribut yang termasuk pada kuadran ini.Tampilan kemasan produk (5), Kekuatan botol saus (8), Waktu pengiriman produk (9), Respon cepat terhadap keluhan (10), Komunikasi antara perusahaan, agen, dan konsumen (11). Pada kuadran D mengindikasikan berlebihan dalam hal kinerjanya, karena walaupun kinerja perusahaan sudah maksimal, namun konsumen menganggapnya tidak begitu penting. Dalam hal ini perusahaan sudah baik, karena tidak ada satu atributpun berada pada kuadran ini.

Evaluasi model Kano dilakukan untuk melihat seberapa baik suatu atribut berperan dalam meningkatkan kualitas produk. Hasil evaluasi model Kano untuksetiap atribut ditampilkan pada tabel berikut ini.

Tabel 3. Kategori Kano Masing-Masing Atribut

\begin{tabular}{llccccccccc}
\hline No. Atribut & A & M & O & R & Q & I & $\begin{array}{c}\text { Koefisien } \\
\text { kinerja }\end{array}$ & $\begin{array}{c}\text { Koefisien } \\
\text { harapan }\end{array}$ & $\begin{array}{c}\text { Kategori } \\
\text { Kano }\end{array}$ \\
\hline 1 & Rasa saos yang enak & 1 & 32 & 0 & 13 & 2 & 2 & 0,20 & $-0,40$ & $\mathrm{M}$ \\
2 & Harga terjangkau & 26 & 1 & 0 & 1 & 18 & 4 & 0,16 & $-0,16$ & $\mathrm{~A}$ \\
\hline
\end{tabular}

\begin{tabular}{|c|c|c|c|c|c|c|c|c|c|c|}
\hline No. & Atribut & A & M & $\mathrm{O}$ & $\mathrm{R}$ & Q & I & $\begin{array}{c}\text { Koefisien } \\
\text { kinerja }\end{array}$ & $\begin{array}{c}\text { Koefisien } \\
\text { harapan }\end{array}$ & $\begin{array}{c}\text { Kategori } \\
\text { Kano }\end{array}$ \\
\hline 3 & $\begin{array}{l}\text { Berat bersih dalam } 1 \\
\text { botol }\end{array}$ & 0 & 0 & 38 & 0 & 1 & 11 & 0 & 0 & $\mathrm{O}$ \\
\hline 4 & $\begin{array}{l}\text { Jaminan halal, } \\
\text { higienis, dan aman }\end{array}$ & 0 & 19 & 0 & 4 & 18 & 9 & 0 & $-0,13$ & M \\
\hline 5 & $\begin{array}{l}\text { Tampilan kemasan } \\
\text { produk }\end{array}$ & 3 & 1 & 0 & 12 & 0 & 34 & 0,07 & $-0,02$ & I \\
\hline 6 & $\begin{array}{l}\text { Produk } \\
\text { didapat }\end{array}$ & 0 & 3 & 31 & 0 & 11 & 5 & 0 & $-0,37$ & $\mathrm{O}$ \\
\hline 7 & Kebersihan botol saos & 0 & 10 & 0 & 26 & 14 & 0 & 0 & $-0,41$ & $\mathrm{R}$ \\
\hline 8 & Kekuatan botol saos & 0 & 6 & 21 & 13 & 10 & 0 & 0 & $-0,22$ & $\mathrm{O}$ \\
\hline 9 & $\begin{array}{l}\text { Waktu pengiriman } \\
\text { produk }\end{array}$ & 0 & 1 & 0 & 1 & 3 & 45 & 0 & $-0,02$ & I \\
\hline 10 & $\begin{array}{l}\text { Respon cepat terhadap } \\
\text { keluhan }\end{array}$ & 0 & 1 & 0 & 7 & 12 & 30 & 0 & $-0,03$ & I \\
\hline 11 & $\begin{array}{l}\text { Komunikasi antara } \\
\text { perusahaan, Agen, dan } \\
\text { konsumen }\end{array}$ & 14 & 0 & 1 & 1 & 5 & 29 & 0,34 & $-0,02$ & I \\
\hline 12 & $\begin{array}{ll}\text { Jaminan } & \text { dari } \\
\text { perusahaan } & \end{array}$ & 0 & 1 & 31 & 15 & 3 & 0 & 0 & $-0,03$ & $\mathrm{O}$ \\
\hline \multicolumn{8}{|c|}{ Rata-Rata } & 0,065 & $-0,145$ & \\
\hline
\end{tabular}

Hasil tabel diatas memperlihatkan bahwa terdapat dua atribut berkategori Must Be, satu atribut berkategori Atractive, dan empat atribut berkategori One-dimensional yang artinya atribut-atribut tersebut mempengaruhi peningkatan kualitas produk. Untuk Atribut yang berkategori Indefferent dan Reverse terdapat masing-masing 4 atribut dan satu atribu yang artinya atribut tersebut tidak memiliki pengaruh terhadap pengaruh kualitas produk.

Hasil integrasi Model IPA-Kano menunjukan bahwa kualitas produk perusahaan masih cukup bagus dan harus dipertahankan, karena pelanggan masih cukup puas terhadap kualitas produk. Namun perusahaan perlu meningkatkan salah satu atribut.

Tabel 4. Integrasi Importance Performance Analysis dan model KANO

\begin{tabular}{|c|c|c|c|c|c|}
\hline No. & Atribut & IPA & KANO & $\begin{array}{l}\text { IPA- } \\
\text { KANO }\end{array}$ & KEPUTUSAN \\
\hline 1 & Rasa saos yang enak & II & $\mathrm{M}$ & SURVIVAL & Dipertahankan 1 \\
\hline 2 & Harga terjangkau & II & A & $\begin{array}{l}\text { Precious } \\
\text { Treasure }\end{array}$ & Dipertahankan 5 \\
\hline 3 & $\begin{array}{l}\text { Berat bersih dalam } 1 \\
\text { botol }\end{array}$ & I & $\mathrm{O}$ & - & - \\
\hline 4 & $\begin{array}{l}\text { Jaminan halal, } \\
\text { higienis, dan aman }\end{array}$ & II & M & SURVIVAL & Dipertahankan 1 \\
\hline 5 & $\begin{array}{l}\text { Tampilan kemasan } \\
\text { produk }\end{array}$ & III & I & - & - \\
\hline 6 & $\begin{array}{l}\text { Produk Mudah } \\
\text { didapat }\end{array}$ & I & $\mathrm{O}$ & - & - \\
\hline 7 & Kebersihan botol saos & I & $\mathrm{R}$ & - & - \\
\hline 8 & Kekuatan botol saos & III & $\mathrm{O}$ & $\begin{array}{l}\text { Difenseles: } \\
\text { Zone }\end{array}$ & Ditingkatkan 4 \\
\hline 9 & $\begin{array}{l}\text { Waktu pengiriman } \\
\text { produk }\end{array}$ & III & I & 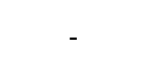 & - \\
\hline 10 & $\begin{array}{l}\text { Respon cepat } \\
\text { terhadap keluhan } \\
\text { Komunikasi antara }\end{array}$ & III & I & - & - \\
\hline & $\begin{array}{l}\text { perusahaan, Agen, } \\
\text { dan konsumen }\end{array}$ & I & I & - & - \\
\hline 12 & $\begin{array}{l}\text { Jaminan dari } \\
\text { perusahaan }\end{array}$ & II & $\mathrm{O}$ & $\begin{array}{c}\text { Major } \\
\text { Weapon }\end{array}$ & Dipertahankan 3 \\
\hline
\end{tabular}

\section{SIMPULAN}

Secara umum pelanggan PD. X sudah cukup puas atas kualitas produk terutama saus PD. X. Namun, jika perusahaan ingin pelanggan tetap setia menggunakan produk saos PD. Maka, fokuskan peningkatan kualitas produk sesuai pada pengintegrasian importance 
performance analysis dan model Kano yang mendapat usulan ditingkatkan. Atribut yang menjadi prioritas yaitu kekuatan botol saos, rasa saos yang enak, jaminan halal, higienis dan aman, jaminan dari perusahaan, serta harga dari produk. Jika perusahaan berfokus meningkatkan atribut tersebut, maka kepuasan pelanggan akan meningkat.

\section{REFERENS}

[1] C. Balqis, Analisa Kualitas Pelayanan PembayaranDana Pensiun Menggunakan Integrasi Importance Performance Analysis dan Model Kano pada BankBTPN Kertajaya Surabaya. Surabaya : Universitas Airlangga. 2016.

[2] S. A. Fudhila, R. Lestari, dan R. husna, Integrasi Metode Importance Performance Analysis dan Model kano Dalam Peningkatan Kualitas Pelayanan(Studi Kasus: Perpustakaan Universsitas Andalas). Jurnal Matematika UNAND. 2016.

[3] I. Ghozali, Aplikasi Analisis Multivariate dengan Program IBM SPSS 19-5/E.Semarang: Universitas Diponegoro. 2011.

[4] A. Indrasari, Integrasi Metode IPA dan Model Kano Dalam Pengembangan Kualitas Pelayanan Perpustakaan. Jurnal Ilmiah Teknik Industri,Vol.3,No. 1. 2015.

[5] D.S. Lestari, Makanan Pedas Paling Dicari Saat Musim Hujan. [ONLINE]. https://lifestyle.okezone.com/read/2015/11/13/298/124 8722/makanan-pedas-paling-dicari-saat-musim-hujan. 2015.

[6] M. Yola and D. Budianto. Analisis kepuasan konsumen terhadap kualitas pelayanan dan harga produk pada supermarket dengan menggunakan metode Importance Performance Analysis (IPA). J. Optimasi Sist. Ind., vol. 12, no. 12, pp. 301-309. 2013. 